\title{
Study on perception of street food vendors about food safety in Lucknow
}

\author{
Rajendra Kumar \\ Amity Business School, Amity University Uttar Pradesh, Lucknow Campus, \\ Gomtinagar Extension (Near Malhaur Railway Station), Lucknow- 226028, U.P., India. \\ E-mail: Rkumar1@1ko.amity.edu, vision.agri@rediffmail.com
}

\begin{abstract}
The street food vendors in Lucknow operate from busy spots all over the city, lining streets, markets and traffic junctions. These foods are encompassing meals, drinks, and snacks and exposed to climate and temperature, unsafe water supplies, unsanitary conditions. A number of factors are taken into consideration when deciding on safety of street food products, such as food freshness, food adulteration, food preparation and perceived food quality. In order of these determinants, this study was conducted in urban area of Lucknow, to know the street food vendor's perceptions about food safety. The results indicate that street vendors perceived that food adulteration $(23.33 \%)$ is main determinants of food safety and followed by food freshness, food preparation, and food quality (16.67\%). Simultaneously, it was found that understanding about food safety was found highest in street food vendors of Chauk area followed by Gomati Nagar, Alambagh. And it was lowest amongst street food vendors of Mahanagar and Aliganj area. Therefore, from the practical standpoint, it is need to create awareness in order to increase awareness about food safety among consumers.
\end{abstract}

Key words: Food safety, adulteration, street vendors, street foods, perception, Lucknow

Paper cited: Kumar, Rajendra (2015). Study on perception of street food vendors about food safety in Lucknow. South Asian J. Food Technol. Environment. 1(2): 136-139.

The street food industry plays an important role in cities and towns of many developing countries both economically and in meeting food demands of city dwellers (Cress-Williams, 2001). Its expansion is linked with urbanization and the need of urban population for both employment and food. The FAO, (1997) pointed out that rural-urban migration gave a sound footing to the activities of the street food industry because of the convenience and the variety it offers.

As a matter of fact, food safety is an important issue that affects anyone who consumes food. The general public might consider safe food as associated with zero risk (no risk at all). Unfortunately there is no public consensus on what constitutes an acceptable risk. Multiple lines of evidence reveal that foods exposed for sale on the roadsides may become contaminated either by spoilage or pathogenic micro-organisms (Bryan et al., 1992; Ashenafi, 1995; WHO, 1984). Evidently, street vended foods have shown epidemiological links with illness (El-Sherbeeny et al., 1985; Saddik et al., 1985; Abdussalam and Kaferstein, 1993). FAO, (1997) further stipulates that street foods raise concern with respect to their potential for serious food poisoning outbreaks.

The street foods in Lucknow are found in all areas and its consumers are young, male, single workers or students, or men with a working wife, and of low to middle socio-economic status. Street foods are exposed to climate and temperature, unsafe water supplies and unsanitary conditions. The street food vendors operate from busy spots all over the city, lining streets, markets and traffic junctions. However, very little is known about how street food vendors themselves perceive about food safety.

In the present study, therefore, an attempt has been made to explore the perception and understanding of health-related following aspects of food safety amongst street food vendors in Lucknow:

a. Food Freshness,

b. Food Adulteration,

c. Food Preparation,

d. Food Quality,

e. All of the Above.

Food safety is an important issue facing current consumers, the food industry and the government. Since consumers cannot themselves easily assess food safety risks, their perception of food safety is, in part, a matter of trust in the food chain. Over the past years, consumers' concern has arisen over food hazards. Amongst these, Bovine Spongiform Encephalopathy (BSE), salmonella, and farm animals fed with antibiotics and hormones are the greatest concern in the UK. Many interested parties including consumers, industries, producers and governments, as well as scientists from a plethora of disciplines, have recently been involved in debates that were initiated by numerous occurrences and 
stirred up by conflicting motivations and influencing factors.

Street foods are ready-to-eat foods and beverages prepared and/or sold by vendors, especially on streets and other public places (Muleta and Ashenafi, 2001).The central characteristic of street foods in this definition is their retail location that is "on the street." To differentiate street food vendors from formal sector food establishments, such as restaurants, the Equity Policy Center (EPOC) adds the further qualification that street foods are sold on the street from "pushcarts or baskets or balance poles, or from stalls or shops having fewer than four permanent walls" (Tinker, 1987). In terms of production, street foods may be centrally processed foods made by the formal sector food industry, or they may be processed within the street food trade either by the vendor her/himself or another smallscale processor. The activities comprising the informal sector are marked by a number of characteristics: ease of entry, reliance on indigenous resources, family/household ownership of the enterprise, small-scale operatives, high labor intensity, use of traditional technology and skills acquired outside the formal education system, and operating in unregulated and competitive markets (Hart, 1973).

Street vendor's perceptions of the food safety present evidence about the confidence people have in it. Regardless of the steps, farmers, businesses and government agencies alike take to insure a safe food supply; but food safety will ultimately reside alongside public perceptions (Andrew and Warland, 2004). Consumer behaviours based on these perceptions, whether accurate or not, can have significant impacts on the food industry (Bruhn et al., 1992; Fein et al., 1995; Frewer et al., 1994; Jordan and Elnagheeb, 1991; Jussaume and Judson, 1992; Lin, 1995; Schafer et al., 1993).

\section{Materials and Methods}

The study titled "Perception of food safety amongst street food vendors in lucknow" was carried out during June 11 to 13, 2013. Sample used for the investigation were from Gomati Nagar, Indira Nagar, Aliganj, Mahanagar, Alambagh and Chauk in Lucknow. Thus total 30 samples of street vendors i.e. 05 venders each from the 06 locations in Gomati Nagar, Indira Nagar, Aliganj, Mahanagar, Alambagh and Chauk were selected randomly and were studied separately using survey method for recording data on issues.

Research Design: In this study qualitative research approach was adopted.

Data Collection Tools: Primary data were collected by conducting a face-to-face interview using a structured close ended questionnaire and the secondary data was collected from magazines, news papers, research papers, journals, etc.

Data Analyses: Collected data was arranged and tabulated in Excel and imported into SPSS version 12.0 (2003) for windows for analysis, including frequencies and $\%$, for all variables.

\section{Results and discussion}

The findings of "Study on perception of street food vendors about food safety in Lucknow" have been arranged as following.

Data on perception issues about food safety amongst street vendors of selected areas of Lucknow were analysed and observation recorded are presented in Table 1. It is evident from above given table that there was not much variability in perception about food safety issues among street vendors of selected areas of Lucknow. The food safety issues like food freshness, food preparation food quality were analyzed separately and findings are as follows: -

Food Freshness: - In Mahanagar $40 \%$ street vendors understood about food freshness issue in food safety followed by $20 \%$ street vendors in Gomtinagar, Aliganj and Chauk while in Indira Nagar and Alambagh vendors do not aware as food freshness is an issue for food safety.

Food adulteration: - In Gomti Nagar and Aliganj 40 $\%$ street vendors understand that food adulteration is an issue of food safety followed by $20 \%$ vendors in Indira Nagar, Alambagh and Mahanagar, respectively whereas in Chauk vendor do not aware.

Food Preparation: In Indira Nagar, Mahanagar and Chauk only $20 \%$ consider as food preparation is an issue of food safety while in other areas they neglect it.

Food quality: In Alambagh $60 \%$ street vendors were aware about food quality is an issue of food safety followed by $40 \%$ vendors of Indira Nagar and Aliganj. In other areas this was only $20 \%$.

Food freshness, food adulteration, food preparation and food quality all were considered as an issues of food safety by street vendors in Chauk (40 percent) followed by $20 \%$ vendors in Gomati Nagar, Indira Nagar, Alambagh respectively while Aliganj and Mahanagar vendors were not giving any consideration about food safety issues (Fig.1).

In Lucknow, food adulteration issues 23.33 $\%$ street vendors perceived as issues of food safety followed by food freshness $(16.67 \%)$ and food preparation. Food quality was given minimum (3.33 $\%$ ) while all of the selected issues taken as an issues of food safety by $16.67 \%$ street vendors of the city (Fig.2) 
Table 1: Food safety Perception of street vendors

\begin{tabular}{|c|c|c|c|c|c|c|c|c|c|c|c|c|c|c|}
\hline $\begin{array}{l}\text { Area } \\
\text { Issues }\end{array}$ & \multicolumn{2}{|c|}{ 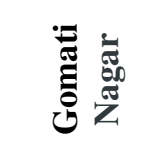 } & \multicolumn{2}{|c|}{ 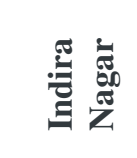 } & \multicolumn{2}{|c|}{ 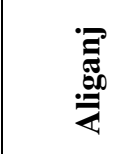 } & \multicolumn{2}{|c|}{ 丞 } & \multicolumn{2}{|c|}{ 表 } & \multicolumn{2}{|c|}{ 兰 } & \multicolumn{2}{|l|}{ ב气 } \\
\hline Food Safety & & $\%$ & & $\%$ & & $\%$ & & $\%$ & & $\%$ & & $\%$ & & $\%$ \\
\hline Food Freshness & 1 & 20 & 0 & 00 & 1 & 20 & 2 & 40 & 0 & 00 & 1 & 20 & 5 & 16.67 \\
\hline Food Adulteration & 2 & 40 & 1 & 20 & 2 & 40 & 1 & 20 & 1 & 20 & 0 & 00 & 7 & 23.33 \\
\hline Food Preparation & 0 & 00 & 1 & 20 & 0 & 00 & 1 & 20 & 0 & 00 & 1 & 20 & 3 & 10.00 \\
\hline Food Quality & 1 & 20 & 2 & 40 & 2 & 40 & 1 & 20 & 3 & 60 & 1 & 20 & 10 & 03.33 \\
\hline All of Above & 1 & 20 & 1 & 20 & 0 & 00 & 0 & 00 & 1 & 20 & 2 & 40 & 5 & 16.67 \\
\hline
\end{tabular}

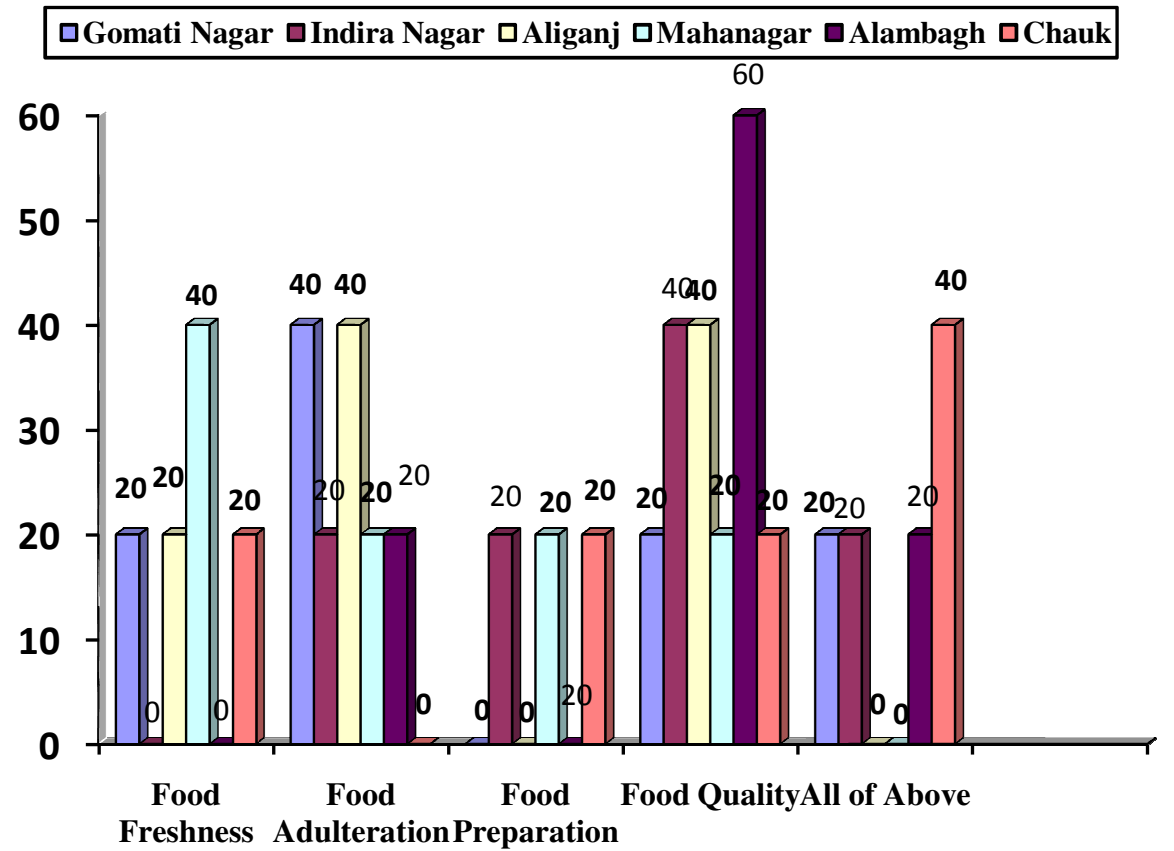

Fig. 1: Bar diagram of perception about food safety issues among street vendors.

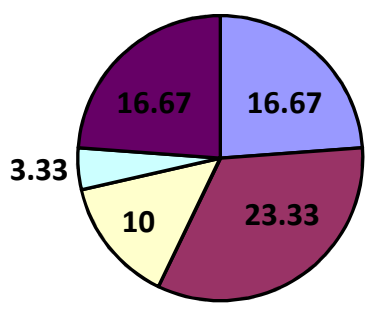

口Food Freshness
$\square$ Food Adulteration
$\square$ Food Preparation
$\square$ Food Quality
$\square$ All of Above

Fig.2: Pie diagram of perception about food safety issues among street vendors in Lucknow 


\section{Conclusions}

The street food vendor's perception and understanding about food safety was found highest in Chauk followed by Gomati Nagar, Alambagh. It was lowest in Mahanagar and Aliganj. Study indicates that $16.67 \%$ street vendors understood that food freshness, food adulteration, food preparation, food quality all are important issues of food safety while $23.33 \%$ street vendors to food adulteration.

\section{Limitations}

This was a limited period study. Therefore, 03 days were very short time to cover all area of Lucknow.

\section{Recommendations}

It is obvious from the study that in Lucknow Street food vendors are not much aware and also not considers food safety issues at street outlets. Therefore, it is need to create awareness in order to increase awareness about food safety among street vendors.

\section{References}

1. Abdussalam, M. and Kaferstein, F.K. (1993). Safety of street foods. World Health Forum. 14:191-194.

2. Andrew, K. and Warland, R. (2004) The Relationship between Sociodemographics and Concern about Food Safety Issues. J Cons Affairs, 38(1), 107-120

3. Ashenafi, M. (1995). Bacteriological profile and holding temperature of ready-to-serve food items in an open market in Awassa, Ethiopia. Trop Geogr Med. 47: 1-4.

4. Bruhn, C., Katherine D.K., Feldman, N., Harwood, J., Ho G., Ivans, E., Kubin, L., Lamp, C., Marshall, M., Osaki, S., Stanford, G., Steinbring, Y., Valdez, I., Williamson, E. and Wunderlich, E. (1991) Consumer Food Safety Concerns and Interest in PesticideRelated Information, J Food Safety. 12: 253262.

5. Bryan, F.L., Teufel, P., Riaz, S., Roohi, S., Qadar, F. and Malik, Z. (1992). Hazards and critical control points of vending operations at a railway station and a bus station in Pakistan. J Food Protect. 55:334-541.

6. Cress-Williams, L. (2001). Food Micro Enterprises for Food Security in an Urban Slum Community in East London: Development of an Awareness-Creating Programme. Unpublished Dissertation. Stellenbosch University.

7. El-Sherbeeny, M.R., Saddik, M. F. and Bryan, F. Z. (1985). Microbiological profiles of food served by street vendors in Egypt. Intern $\mathbf{J}$ Food Microbiol. 2:355-362.

8. Food and Agricultural Organization (FAO). (1997). Street foods: Report of an FAO Expert Consultation Jogjakarta, Indonesia December 5-9, 1988. Food and Nutrition Paper no.46. Rome: FAO.

9. Fein, Sara, Lin, C.T. and Levy, A. (1995) Food borne Illness: Perceptions, Experience, and Preventive Behaviors in the United States, J Food Protec. 58(12): 1405-1411.

10. Frewer, L., Shepherd, R. and Sparks, P. (1994) The Interrelationship between Perceived Knowledge, Control, and Risk Associated with a Range of Food-related Hazards Targeted at the Individual, Other People, and Society. J Food Safety. 14: 19-40.

11. Hart, K. (1973). Informal income opportunities and urban employment in Ghana. J Modern African Studies 2(1): 61-89

12. Jordan, Jeffrey and Abdelmoneim Elnaghee, B. (1991). Public Perceptions of Food Safety. J Food Distrib Res. Sept. (1991): 13-32.

13. Jussaume, Raymond, Jr. and Judson, D.H. (1992). Public Perceptions about Food Safety in the United States and Japan. Rural Socio. 57(2): 235-249.

14. Lin, Chung-Tung Jordan. (1995). Demographic and Socioeconomic Influences on the Importance of Food Safety in Food Shopping. Agric Resource Econ Rev, 24(2):190-198.

15. Muleta, D. and Ashenafi, M. (2001). Salmonella, Shigella and Growth potential of other food-bourne pathogens in Ethiopian street vended foods. East African Med J. 7(11) 576-580.

16. Saddik, M.F., El-Sherbeeny, M.R., Mousa, B.M., El-Akkad, A. and Bryan, F.L. (1985). Microbiological profile and storage temperatures of Egyptian fish and other sea foods. J. Food Protect. 48:403-406.

17. Schafer, R., Schafer, E., Bultena, G. and Hoiberg, E. (1993) Food Safety: An Application of the Health Belief Model. J Nutri Educ. 25(1): 17-23.

18. SPSS, Version 12.0. (2003). SPSS Web site at http://www.spss.com/worldwide

19. WHO. (1984). The role of Food Safety in Health and Development: Report of a joint FAO/WHO Expert Committee on Food Safety. Technical Report Series, No. 705. 